\title{
Cytotoxic Effect of Boron Application on Glioblastoma Cells
}

\author{
Hasan Emre AYDIN¹, Meliha KOLDEMIR GUNDUZ², Ceren KIZMAZOGLU³ ${ }^{3}$ Turan KANDEMIR ${ }^{4}$, Ali ARSLANTAS ${ }^{5}$ \\ ${ }^{1}$ Kutahya University of Health Sciences, Department of Neurosurgery, Kutahya, Turkey \\ ${ }^{2}$ Kutahya University of Health Sciences, Department of Medical Services and Techniques, Kutahya, Turkey \\ ${ }^{3}$ Dokuz Eylul University, School of Medicine, Department of Neurosurgery, Izmir, Turkey \\ ${ }^{4}$ Yunus Emre State Hospital, Department of Neurosurgery, Eskisehir, Turkey \\ ${ }^{5}$ Eskişehir Osmangazi University, School of Medicine, Department of Neurosurgery, Eskisehir, Turkey
}

Corresponding author: Turan KANDEMIR turankandemir26@gmail.com

\section{ABSTRACT}

AIM: To investigate the cytotoxic effects of boron application at different doses on U-87 MG glioblastoma cells

MATERIAL and METHODS: The T98G (ATCC $®$ CRL-1690'TM) glioblastoma cell strain used in the study was acquired from the American Type Culture Collection (ATCC) (Manassas, USA). Boric acid solution was prepared by mechanical mixing in the medium. Afterwards, $2.5 \mathrm{mM}, 25 \mathrm{mM}$ and $50 \mathrm{mM}$ boron were each added to U87-MG glioblastoma cells and incubated for 48 hours. The cytotoxic effects on the cells was determined using the MTT (Methylthiazole diphenyl tetrazolium) test 48 hours after boron application.

RESULTS: IC50 value was detected as $17 \mathrm{mM}$ in the 48-hour boric acid application on U-87 MG glioblastoma cells

CONCLUSION: Boron treatment might be an effective approach for glioblastoma.

KEYWORDS: Boron treatment, Glioblastoma, Cytotoxic effects

ABBREVIATIONS: ATCC: American type culture collection, MTT: Methylthiazole diphenyl tetrazolium, GBM: Glioblastoma, BNCT: Boron neutron capture therapy, EMEM: Eagle's minimum essential medium, FBS: Fetal bovine serum, FDA: Food and Drug Administration

\section{INTRODUCTION}

A $S$ the most aggressive form of glioma, glioblastoma (GBM) is the most common primary brain tumour in adults (31). The World Health Organization classifies it as a stage IV glioma and its prevalence is approximately $3 / 100.000$ individuals (1).

It remains a mortal disease with an extremely low prognosis despite the availability of different modern GBM treatments (27). Regarding standard surgical treatment application, radiotherapy and chemotherapy have been applied. With a highly invasive character, glioblastoma cells do not only escape surgery and focal treatments, but also resist the available radio- and chemotherapeutic approaches (13). A survival rate of approximately 15 months after diagnosis (32), and being a disease with a poor prognosis make glioblastoma an important public health problem. Thus, it is important to develop new treatment strategies that prevent the invasiveness of glioblastoma in order to treat this mortal disease.

New glioblastoma treatments are being developed and tested. Tumour vaccine treatment in GBM aims to promote the immune systems of the patients to produce immune cells by transferring tumor-related antigens. In this regard, Dendritic cell and Heat Shock protein vaccine treatment studies are ongoing $(8,10)$.
Hasan Emre AYDIN $\quad$ (D): 0000-0002-8932-1542

Meliha KOLDEMIR GUNDUZ :(D): 0000-0003-0969-6377

Ceren KIZMAZOGLU (1) : 0000-0001-6146-0842
Turan KANDEMIR (1) : 0000-0002-6230-0645

Ali ARSLANTAS (D) : 0000-0002-0847-9015 
Tumor cells are infected and destroyed by oncolytic viruses. Clinical studies have shown that the use of recombinant adenovirus DNX-2401, poliomyelitis-rhinovirus chimera and parvovirus $\mathrm{H}-1$ lengthens the survival in GBM patients (30).

Boron neutron capture therapy (BNCT) kills tumour cells selectively, depending on the preloaded boron neutron capture reaction during low energy thermal neutron irradiation of the tumour cells (20).

In addition, boron element, which can be taken with the daily diet and can easily be applied with the available treatments with proven anticarcinogenic effects can be used for glioblastoma treatment. Boron compounds taken orally are quickly turned into boric acid in the gastrointestinal system and distributed to the tissues through the blood. Boron atoms in biological systems interact with proteins through strong hydrogen and weak covalent bonds providing biological effects (12). Natural boron compounds with antibacterial, antiviral and anticancer activities are used for treatment in pharmaceutic formulations $(5,28)$. Due to the high proliferative rates and metabolisms, cancer cells need a lot of energy. Boron damages cancer cells by closing the primary energy gain paths in prostate, cervical, lung and esophageal cancers (6). Thus boron compounds deserve to be examined within the scope of neurological and oncological diseases in future studies.

U-87 MG cell strain covers epithelial cells derived from human malignant gliomata and U87MG is commonly used in human glioma research. U87-MG cell strain preferred by many research groups is suggested as a classical cell strain for glioblastoma (4). The aim of this study was to investigate the cytotoxic effects of boron application on U-87 MG glioblastoma cells.

\section{MATERIAL and METHODS}

\section{U87-MG Glioblastoma Cell Culture}

T98G (ATCC $®$ CRL-1690'M) glioblastoma cell strain used in the study was acquired from the American Type Culture Collection (ATCC) (Manassas, USA). Before starting the cell culture study, EMEM (Eagle's Minimum Essential Medium containing ATCC, USA) medium + 10\% Fetal Bovine Serum (FBS; ATCC, USA) + penicillin/streptomycin (100 $\mathrm{gg} / \mathrm{ml}$; Gibco, US) was prepared in a ultraviolet cabin under sterile conditions.

\section{Boron Application in U87-MG Glioblastoma Cells}

Boric acid solution was prepared through mechanical mixing in the medium. Afterwards, $2.5 \mathrm{mM}, 25 \mathrm{mM}$ and $50 \mathrm{mM}$ boron were each added to the U87-MG glioblastoma cells and incubated for 48 hours. Only culture medium was added to the control cells.

\section{MTT Test Application in U87-MG Glioblastoma Cells}

The ratio of viable cells in the cell strain was colorimetrically detected using the MTT [3-(4,5-dimethyldiazol-2-yl)-2,5 diphenyl Tetrazolium Bromide] method. The test was performed according to the principle of yellow MTT stain emerging by disruption of the tetrazolium ring turning into dark blue-purple formazan product. Cells were incubated in $35 \mathrm{~mm} \times 10 \mathrm{~mm}$ sterile petri dishes at $37^{\circ} \mathrm{C}$ and $5 \% \mathrm{CO}_{2}$. Different doses of boron were applied on the cells. We placed $2 \mathrm{ml}$ of medium containing $0.5 \mu \mathrm{g} / \mu \mathrm{l} \mathrm{MTT}$ and $0.5 \%$ FBS in each dish and incubated for four hours. After the four hours, MTT medium in the petri dishes was aspirated and $200 \mu \mathrm{l} 3 \%$ SDS was added into each petri dish and mixed. Then $1 \mathrm{ml} 40 \mathrm{mM} \mathrm{Hcl} /$ isopropanol was added and mixed. The cells were homogenised with a pipette and $\mathrm{HCl} /$ isopropanol was used for dilution. The stain volume acquired at the end of analysis was measured at 570 $\mathrm{nm}$ wavelength absorbance using SmartSpec Plus spectrophotometer (Bio-Rad Laboratories, Inc., Hercules, CA, USA) and the viable cell ratio was determined (34). GraphPad Prism 5.0 program (GraphPad Software, Inc., La Jolla, CA, USA) was used for data analysis and a graphic was formed. To calculate the $\mathrm{IC}_{50}$ value, data were normalized by nonlinear regression analysis using the GraphPad Prism 5.0 program.

\section{Cell Viability Analysis}

Cell viability ratios were calculated in comparison with the untreated control cells to determine the effect of boron application. Viability of the untreated cells was regarded as $100 \%$ and the viability percentages of the cells were calculated as follows:

\% viability ratio: (Treated cell/ untreated cell) X 100

\section{RESULTS}

The cells were cultured in a standard medium for 24 hours before boron application on the U87-MG Glioblastoma cells. Later, $2.5 \mathrm{mM}, 25 \mathrm{mM}$ and $50 \mathrm{mM}$ boron was added to each cell culture medium and incubated for 48 hours. Only culture medium was added to the control cells. MTT test was performed on the cells after boron application. Using the GraphPad Prism 5.0 program, statistical analysis was conducted from the data acquired through the MTT test. Based on the statistical analysis following $2.5 \mathrm{mM}, 25 \mathrm{mM}$ and $50 \mathrm{mM}$ boron application on glioblastoma cells for 48 hours, $\mathrm{IC}_{50}$ value of boron in the $48^{\text {th }}$ hour was calculated as $17 \mathrm{mM}$ (Figure 1). This result shows that boron has a cytotoxic effect on U87-MG glioblastoma cells.

To analyse the percentage survival ratios of U87-MG glioblastoma cells due to the application of boron at different doses, $2.5 \mathrm{mM}, 25 \mathrm{mM}$ and $50 \mathrm{mM}$ boron were applied for 48 hours on the multiplied cells until it reached the logarithmic phase in $35 \times 10 \mathrm{~mm}$ petri dishes. Then, the MTT cytotoxicity test was performed (Figure 2). Compared to the controls, the percentage cell viability was calculated to be $90 \%$ as the result of the $2.5 \mathrm{mM}$ boron application, $46 \%$ for the $25 \mathrm{mM}$ boron application and $23 \%$ for the $50 \mathrm{mM}$ boron application. In addition, the $50 \mathrm{mM}$ boron was found to have a fatal effect on glioblastoma cells. It was found that $25 \mathrm{mM}$ but not 2.5 $\mathrm{mM}$ boron application had a multiplication-preventing effect on U87-MG cells (Figure 2). High dose boron application was observed to have a cytotoxic effect on glioblastoma cells.

\section{DISCUSSION}

Surgery, adjuvant radiotherapy and chemotherapy are among the current treatment options for glioblastoma patients. Based 


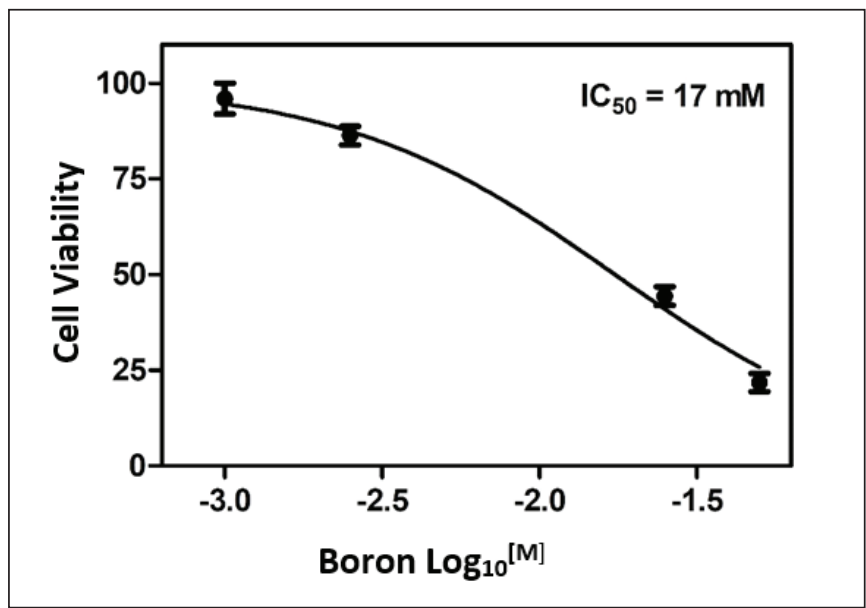

Figure 1: Boron $\mathrm{IC}_{50}$ value in U87-MG glioblastoma cells and the $\%$ survival graphic. $I C_{50}$ value of the cells treated with different concentrations of boron for 48 hours was detected with the MTT test.

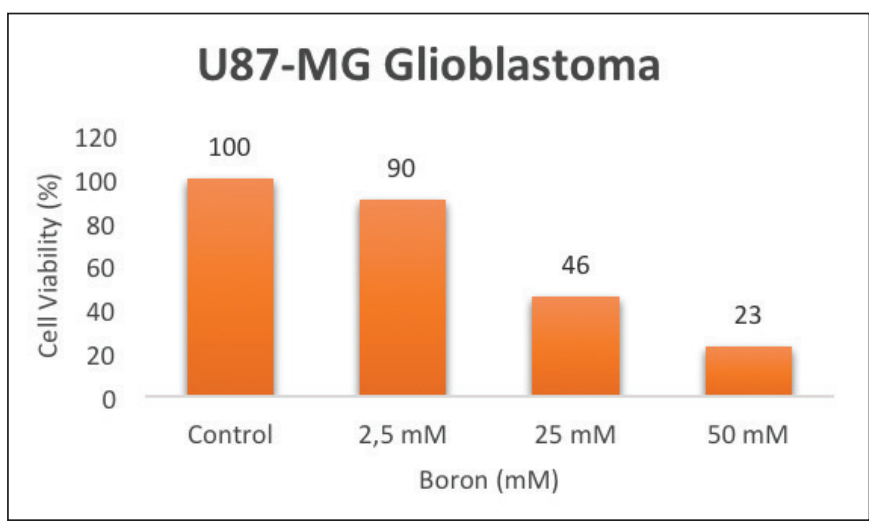

Figure 2: Cytotoxic effect of boron application at different doses on U87-MG cells. MTT test was performed after treating the U87MG cells with $2.5 \mathrm{mM}, 25 \mathrm{mM}$ and $50 \mathrm{mM}$ boron for 48 hours.

on previous studies, the median survival period is extended by approximately two months when radiotherapy is applied in addition to chemotherapy following surgical treatment $(16,17)$. It is suggested that more research is required to determine its therapeutic strategies in alternative in vitro and in vivo models in addition to the current treatments to extend survival.

Boron atoms present an antibacterial, antiviral and anticancer character by interacting with proteins through hydrogen and covalent bonds in living systems (6). Due to their constantly dividing nature, cancer cells have high metabolic activities and need more energy compared to healthy cells. Boron compounds cause less energy production by affecting the biochemical cycles that produce energy in cancer cells, thereby negatively affecting the proliferation of cancer cells (22).

Being common in nature, boron and its compounds can also be taken through the diet. Previous studies have shown that boron may affect the brain functions and cognitive performance (26). The brain is among the parts of the body where boron compounds are most commonly found after being taken into the body. In the experiment by $\mathrm{Ku}$ et al., it was reported that boron I reached a constant level in the brain and hypothalamus in addition to some other parts of the body, after a boric acid diet for seven days (23). In another study, boric acid level in the gray substance of the brains of laboratory animals sacrificed after boric acid diet was found to be higher than those in the white substance (25). It was observed that boric acid treatment significantly decreased tissue damage, inflammation and oedema in an ischemia/ reperfusion model of the spinal cord (21).

Boron compounds have started to be used in studies on different cancer types in recent years. The cytotoxic effects of boron derivative compounds such as boric acid, phenylboronic acid, dihydroxy boron and sodium tetraborate were detected on B16F10 murine melanoma, HL-60 and U-937 human leukemia cells $(11,14)$. In their study, Mahabir et al. stated that high boron intake had a preserving effect against lung cancer (24). In a study investigating the effect of boron application on H1299 and COR-L23p lung cancer at different doses, Al-Ali and Gonzalez-Sarmiento reported that $5 \mathrm{mM}$ boric acid concentration did not create a significant effect on cell growth, but $25 \mathrm{mM}$ boric acid concentration inhibited cells (2). In a study investigating the 24 hour effect of boric acid on DU-145 human prostate cancer cell strain, Hacioglu et al. showed that the cell viability ratio was $61 \%$ in $6.25 \mathrm{mM}$ boric acid concentration and $45.8 \%$ in $12.5 \mathrm{mM}$ boric acid concentration (18). In a study investigating the cytotoxic effects of boron trioxide on L929 fibroblast cells and DLD-1 colorectal adenocarcinoma cells, Albuz et al. found that the cytotoxic activity was $55.78 \%$ for DLD-1 and $81.64 \%$ for L929, when $10 \mu \mathrm{g} / \mathrm{mL}$ concentration was used (3). This condition shows that the cancer cells are more resistant than normal cells.

In their study investigating the effects of highly water-soluble nano-structured boron nitride compounds which can be used in BNCT on HeLa (cervical cancer) and MCF-7 (human breast adenocarcinoma) cells, Singh et al. found cytotoxicity ratios of $60 \%$ and $45 \%$, respectively, for $2 \mathrm{mg} / \mathrm{mL}$ drug dose (29). Wittig et al. reported that boron use for GBM was promising for $B N C T$ research in the study investigating the ${ }^{10} \mathrm{~B}$-accumulation in human glioblastoma multiforme (U87MG) cells (33). Based on the studies in literature, application of high dose boron/ boron compounds in different cancer types demonstrates a cytotoxic effect in cells, similar to the finding of our study. We found that the survival ratio was $25 \%$ for $50 \mathrm{mM}, 46 \%$ for 25 $\mathrm{mM}$ and $90 \%$ for $2.5 \mathrm{mM}$ boron application on U87-MG cells.

Boric acid is the main product of boron following hydrolysis after oral intake. Bortezomib [N-2,3-pyrazine)carbonyl-Lphenylalanine-L-leucine-boronic acid] is the first Food and Drug Administration (FDA) approved antineoplastic which is made of boron and is effective through proteasome inhibition. It is used especially in multiple myeloma and nonhodgkin lymphoma treatment. Peak plasma concentration of Bortezomib is $25-50 n M(6,35)$. 
In their study, Bittencourt et al. proved that Bortezomib had an antiangiogenic effect on U87 cells at $20 \mathrm{nM}(7)$. In our study, $25 \mathrm{nM}$ and $50 \mathrm{nM}$ were also found to be effective.

In previous animal studies, it was shown that boric acid inhibited Histon deacetylase functioning in regulating gene expressions. Histon deacetylase inhibition prevents cancer formation by inhibiting cell growth (15). It was considered that this characteristic could be used for cancer treatment. As a weak Lewis acid, boric acid also resembles a carbon atom chemically (9). Being able to easily enter the cells with its small atom diameter, boric acid functions as a drug delivery vehicle in anti-cancer treatment. Boron capture therapy is its most famous example. In addition to these characteristics, having a low-toxicity character, excretion in a short period through urine without being metabolized and easy acquisition gives it an advantage over other medical therapies in cancer treatment (19).

In our study, while $50 \mathrm{mM}$ boron application had a lethal effect on glioblastoma cells and $25 \mathrm{mM}$ boron application had a multiplication-preventive effect on U87-MG cells, we found that $2.5 \mathrm{mM}$ boron application did not show a multiplicationpreventive effect on glioblastoma cells. High dose boron application was observed to have a cytotoxic effect on glioblastoma cells. Hacioglu et al. found $\mathrm{IC}_{50}$ rate as $10.77 \mathrm{mM}$ in boric acid application with different concentrations of 12.5 , $6.5,3.13,1.56,0.78,0.39$ and $0.19 \mathrm{mM}$ for 24 hours on DU145 cells (18). Based on the statistical analysis, after $2.5 \mathrm{mM}$, $25 \mathrm{mM}$ and $50 \mathrm{mM}$ boron application on glioblastoma cells for 48 hours, $I_{50}$ value of boron in the 48th hour was calculated as $17 \mathrm{mM}$. This result shows that boron has a cytotoxic effect on U87-MG glioblastoma cells.

\section{CONCLUSION}

GBM is a disease with a poor prognosis due to the limitations and lack of significant improvements in its treatment. Considering its complexity and treatment difficulties, new therapeutic approaches are needed to improve the results for the patients. We investigated the cytotoxic role of boron application on GBM treatment in our study and found that high-dose boron application had a fatal effect on GBM cells and boron application at non-toxic doses did not inhibit cell proliferation. As a result of our study, it was shown that highdose boron application is a promising approach for GBM treatment. We think that our findings provide an important background for future studies. More studies are needed to determine the efficiency of boron application in GBM treatment.

\section{ACKNOWLEDGEMENTS}

Preparation for publication of this article is partly supported by Turkish Neurosurgical Society.

\section{REFERENCES}

1. Adamson C, Kanu OO, Mehta Al, Di C, Lin N, Mattox AK, Bigner DD: Glioblastoma multiforme: A review of where we have been and where we are going. Expert Opin Investig Drugs 18:1061-1083, 2009

2. Al-Ali R, Gonzalez-Sarmiento R: High concentrations of boric acid induce autophagy in cancer cell lines. bioRxiv 193441, 2017

3. Albuz O, Dulger D, Tunali BC, Aydin F, Yalcin S, Turk M: Effects of B2O3 (boron trioxide) on colon cancer cells: Our first-step experience and in vitro results. Turk J Biol 43:209-223, 2019

4. Allen $M$, Bjerke $M$, Edlund $H$, Nelander S, Westermark B: Origin of the U87MG glioma cell line: Good news and bad news. Sci Transl Med 8(354):354re3, 2016

5. Altinoz MA, Ince B, Sav A, Dincer A, Cengiz S, Mercan S, Yazici Z, Bilgen MN: Human brains found in a fire-affected 4000-years old Bronze Age tumulus layer rich in soil alkalines and boron in Kutahya, Western Anatolia. Homo 65:33-50, 2014

6. Altinoz MA, Topcu G, Elmaci İ: Boron's neurophysiological effects and tumoricidal activity on glioblastoma cells with implications for clinical treatment. Int J Neurosci 129:963-977, 2019

7. Bittencourt L, Negreiros-Lima G, Sousa L, Silva A, Souza I, Ribeiro R, Dutra M, Silva R, Dias A, Soriani F: G3BP1 knockdown sensitizes U87 glioblastoma cell line to Bortezomib by inhibiting stress granules assembly and potentializing apoptosis. J Neurooncol 144:463-473, 2019

8. Bloch O, Crane CA, Fuks Y, Kaur R, Aghi MK, Berger MS, Butowski NA, Chang SM, Clarke JL, McDermott MW: Heatshock protein peptide complex-96 vaccination for recurrent glioblastoma: A phase II, single-arm trial. Neuro Oncol 16:274279, 2014

9. Bradke TM, Hall C, Carper SW, Plopper GE: Phenylboronic acid selectively inhibits human prostate and breast cancer cell migration and decreases viability. Cell Adh Migr 2:153-160, 2008

10. Bregy A, Wong TM, Shah AH, Goldberg JM, Komotar RJ: Active immunotherapy using dendritic cells in the treatment of glioblastoma multiforme. Cancer Treatment Reviews 39:891907, 2013

11. Canturk Z, Tunali Y, Korkmaz S, Gulbas Z: Cytotoxic and apoptotic effects of boron compounds on leukemia cell line. Cytotechnology 68:87-93, 2016

12. Das BC, Thapa P, Karki R, Schinke C, Das S, Kambhampati S, Banerjee SK, Van Veldhuizen P, Verma A, Weiss LM: Boron chemicals in diagnosis and therapeutics. Future Med Chem 5:653-676, 2013

13. de Gooijer MC, Navarro MG, Bernards R, Wurdinger T, van Tellingen O: An experimenter's guide to glioblastoma invasion pathways. Trends Mol Med 24:763-780, 2018

14. Deshayes S, Cabral H, Ishii T, Miura Y, Kobayashi S, Yamashita T, Matsumoto A, Miyahara Y, Nishiyama N, Kataoka K: Phenylboronic acid-installed polymeric micelles for targeting sialylated epitopes in solid tumors. J Am Chem Soc 135:15501-15507, 2013 
15. Di Renzo F, Cappelletti G, Broccia ML, Giavini E, Menegola E: Boric acid inhibits embryonic histone deacetylases: a suggested mechanism to explain boric acid-related teratogenicity. Toxicol Appl Pharmacol 220:178-185, 2007

16. Friedman HS, Prados MD, Wen PY, Mikkelsen T, Schiff D, Abrey LE, Yung W, Paleologos N, Nicholas MK, Jensen R: Bevacizumab alone and in combination with irinotecan in recurrent glioblastoma. J Clin Oncol 27:4733-4740, 2009

17. Gilbert MR, Dignam JJ, Armstrong TS, Wefel JS, Blumenthal DT, Vogelbaum MA, Colman H, Chakravarti A, Pugh S, Won $M$, Jeraj R, Brown PD, Jaeckle KA, Schiff D, Stieber VW, Brachman DG, Werner-Wasik M, Tremont-Lukats IW, Sulman EP, Aldape KD, Curran Jr WJ, Mehta MP: A randomized trial of bevacizumab for newly diagnosed glioblastoma. $\mathrm{N}$ Engl $\mathrm{J}$ Med 370:699-708, 2014

18. Hacioglu C, Kar F, Kacar S, Sahinturk V, Kanbak G: High concentrations of boric acid trigger concentration-dependent oxidative stress, apoptotic pathways and morphological alterations in DU-145 human prostate cancer cell line. Biol Trace Elem Res 193:400-409, 2020

19. Hawthorne MF, Shelly K: Liposomes as drug delivery vehicles for boron agents. J Neuro-Oncol 33:53-58, 1997

20. Kanemitsu T, Kawabata S, Fukumura M, Futamura G, Hiramatsu R, Nonoguchi N, Nakagawa F, Takata T, Tanaka H, Suzuki M, Masunaga SI, Ono K, Miyatake SI, Nakamura H, Kuroiwa T: Folate receptor-targeted novel boron compound for boron neutron capture therapy on F98 glioma-bearing rats. Radiat Environ Biophys 58:59-67, 2019

21. Koc ER, Gokce EC, Sonmez MA, Namuslu M, Gokce A, Bodur AS: Borax partially prevents neurologic disability and oxidative stress in experimental spinal cord ischemia/reperfusion injury. J Stroke Cerebrovasc Dis 24:83-90, 2015

22. Korkmaz M, Uzgoren E, Bakirdere S, Aydin F, Ataman OY: Effects of dietary boron on cervical cytopathology and on micronucleus frequency in exfoliated buccal cells. Environ Toxicol 22:17-25, 2007

23. Ku WW, Chapin RE, Moseman RF, Brink RE, Pierce KD, Adams KY: Tissue disposition of boron in male Fischer rats. Toxicol Appl Pharmacol 111:145-151, 1991

24. Mahabir S, Spitz M, Barrera S, Dong Y, Eastham C, Forman M: Dietary boron and hormone replacement therapy as risk factors for lung cancer in women. Am J Epidemiol 167:10701080, 2008
25. Moseman RF: Chemical disposition of boron in animals and humans. Environ Health Perspect 102 Suppl 7:113-117, 1994

26. Penland JG: Dietary boron, brain function, and cognitive performance. Environ Health Perspect 102:65-72, 1994

27. Rock K, McArdle O, Forde P, Dunne M, Fitzpatrick D, O'Neill B, Faul C: A clinical review of treatment outcomes in glioblastoma multiforme-the validation in a non-trial population of the results of a randomised Phase III clinical trial: Has a more radical approach improved survival? $\mathrm{Br} J$ Radiol 85:e729-e733, 2012

28. Scorei RI, Popa Jr R: Boron-containing compounds as preventive and chemotherapeutic agents for cancer. Anticancer Agents Med Chem 10:346-351, 2010

29. Singh B, Kaur G, Singh P, Singh K, Kumar B, Vij A, Kumar M, Bala R, Meena R, Singh A, Thakur A, Kumar A: Nanostructured boron nitride with high water dispersibility for boron neutron capture therapy. Scientific Reports 6:35535, 2016

30. Stepanenko AA, Chekhonin VP: Recent advances in oncolytic virotherapy and immunotherapy for glioblastoma: A glimmer of hope in the search for an effective therapy? Cancers 10:492, 2018

31. Stupp R, Mason WP, Van Den Bent MJ, Weller M, Fisher B, Taphoorn MJ, Belanger K, Brandes AA, Marosi C, Bogdahn U, Curschmann J, Janzer RC, Ludwin SK, Gorlia T, Allgeier A, Lacombe D, Cairncross JG, Eisenhauer E, Mirimanoff RO, European Organisation for Research and Treatment of Cancer Brain Tumor and Radiotherapy Groups; National Cancer Institute of Canada Clinical Trials Group: Radiotherapy plus concomitant and adjuvant temozolomide for glioblastoma. $\mathrm{N}$ Engl J Med 352:987-996, 2005

32. van Schaijik B, Wickremesekera AC, Mantamadiotis T, Kaye AH, Tan ST, Stylli SS, Itinteang T: Circulating tumor stem cells and glioblastoma: A review. J Clin Neurosci 61:5-9, 2019

33. Wittig A, Moss RL, Sauerwein WAG: Glioblastoma, brain metastases and soft tissue sarcoma of extremities: Candidate tumors for BNCT. Appl Radiat Isot 88:46-49, 2014

34. Yerlikaya A, Okur E, Ulukaya E: The p53-independent induction of apoptosis in breast cancer cells in response to proteasome inhibitor bortezomib. Tumor Biology 33:1385-1392, 2012

35. Yin D, Zhou H, Kumagai T, Liu G, Ong JM, Black KL, Koeffler HP: Proteasome inhibitor PS-341 causes cell growth arrest and apoptosis in human glioblastoma multiforme (GBM). Oncogene 24:344-354, 2005 